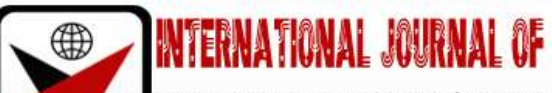

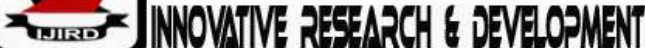

ISSN $2278-0211$ (Online)

\section{The Application of Risk Management Practices at PT XYZ: Case Study at Industrial Estate Company in 2018)}

Said Djamaluddin
Postgraduate Lecturer of Mercu Buana University, Jakarta, Indonesia
Suhendi
Postgraduate Alumni of Mercu Buana University, Jakarta, Indonesia
Aty Herawati
Postgraduate Lecturer of Mercu Buana University, Jakarta, Indonesia

\section{Abstract:}

The aim of this research is to describe the application of risk management practices within the organization of PT XYZ, the company that runs the business of managing real estate. In this context, this research is to explore qualitatively the implementation of risk management along all organizational units within the company. Furthermore, this research would like to identify the maturity level of such risk management application within PT XYZ.

The method used in this research is mainly referred to the principles of Enterprise Risk Management (ERM) based on the practices introduced by ISO 31000. This is such a qualitative field research utilizing descriptive method and analysis. The process of primary data collection is done through guided interviews where related key informant of every organizational unit is thoroughly interviewed in order to gain detailed information related to the application of risk management at his or her unit. In this context, a list of interview points is designed to function as the interview guideline and applied as the main research instruments herein. The key informants of the research are those who empirically lead or dominantly participate on the process of risk management analysis in their own operational units. In case of unavailability of determined primary informant at any organizational unit, this research also provides secondary informant candidate to guarantee the completion of primary data collection. Hence, all research informants are completely interviewed. Then, the primary data are analyzed using descriptive analysis technique. In doing so, the template of analytical steps provided by Enterprise Risk Management is mostly adopted in order to formulate the results of data analysis.

Conclusively, this research uncovers empirical findings PT XYZ has, to some extent, implemented Risk Management Analysis along the year of 2018, such as: risk identification, risk level identification, risk measurement using the framework introduced by ISO 31000.

Finally, this research recommends the following managerial action plans to take into account by the management of PT XYZ:1. Increase Board of Directors support,2. Broaden Risk Awareness Campaigns and 3. Increase Environmental Analysis Skills for all Risk Owners

Keywords: Risk management, risk assessment, risk mitigation, and ISO 31000

\section{Introduction}

In 2017 and 2018, most companies have experienced various uncertainties affected by business environmental changes in the global market(CRMS Indonesia, 2018).Risk management has now become one of the most crucial activities in business practices in the fields of banking, manufacturing, trade, services, and in other types of business. Hery (2016: 9) revealed that risk challenges can stem from the impact of globalization, market complexity, scarcity of qualified personnel, technological evolution, product differentiation, tighter business regulations, and the like. Therefore, it is a compulsory task for all companies' management to implement risk management; otherwise, their business tends to experience such terrible losses in the future.

The level of maturity of Risk Management application in Indonesia ranges from medium level $(26,78 \%$ companies)to high or good level (29.78\%). Meanwhile, the percentage of $18.03 \%$ of the companies in Indonesia is identified to have optimal level of maturity due to Risk Management application. This means that most companies in Indonesia have already applied the principles and framework of Risk Management process, the implementation of monitoring system. As well, these practices are conducted in integration with the company's business processes (CRMS, 2018).

Furthermore, the study of Soleh, et al. (2016) revealed that manual or semi-computerized risk assessment methods did not work effectively in terms of time because they were still handwritten or typed using Microsoft Excel. 
The research conducted by Reim et al. (2016) concludes that risk management is a very important aspect for Alpha Corporation (a manufacturing company in Sweden) to improve the Operation Product-Service System (PSS). Operational risks such as technical, behavioral, and competency risks in the delivery of goods have been treated through common risk treatments such as: avoiding, reducing, transferring, and accepting risks. Overall, operational risks must be anticipated in such a way through risk management principles to ensure that the objectives of the company (business) can be optimally achieved.

The risk management application can become a guideline for the organization in achieving its stated goals. The implementation of risk management is the responsibility of the management of the company. In doing this, the management should involve all related figures of the company to develop common understanding among them. The formulation of risk management is carried out by top management and is applied to each work unit throughout the organization. Every work unit has to identify riskcharacteristics and the risk consequent impacts before formulating suitable treatment. Different characteristics or different types operational risks need different ways of risk treatments at all levels of organizational units of the companies.

The implementation of integrated risk management must become an integral part of the implementation of the company / organization management system. This means that risk management application should become one of the ways to create continuous improvement system in order to guarantee the survival of the companies in the market. As an entity, PT. XYZ is inseparable from the obligation to consistently implement risk management in order to deal with the market's uncertainty. In addition to risk identification, the management should also design proper mitigation programs to achieve the company's goals. Furthermore, the implementation of risk management analysis is also meant to improve or increase not only the shareholder value of PT. XYZ but the value of stakeholders of PT XYZ as well. First of all, the company has to conduct risk assessment activities and the company's risk profile to develop the company's risk policies for the better sake of the company in the future.

In accordance with SOE (State-Owned Enterprise) Ministerial Regulation Number PER-01 / MBU / 2011 dated August 1, 2011 concerning the Implementation of Good Corporate Governance in State-Owned Enterprises, PT XYZ, as one of the business entities whose shares are owned by the state, has an obligation to implement Risk Management in the company's business activities.Considering risks faced in running its business, PT XYZ management must be able to recognize the categories of those risks by which the company should be creative to formulate ways to handle these risks. This requires the preparation of risk profiles and policies for applying risk management based on Enterprise Risk Management (ERM) and ISO 31000.

Susilo and Kaho (2018: 7) revealed that the ISO 31000 standard has a much broader perspective (can be applied in various scopes and activities) and is more conceptual compared to other standards available. This is indicated by the existence of explicitly stated principles and quality management framework known as "Plan-Do-Check-Action" Scheme (PDCA Scheme). Accordingly, this research is expected to provide added value to the company's operations due to the Risk Management application at any level of organizational units of PT XYZ. In addition, this research will hopefully display empirical findings, which will serve as good example and will be very beneficial for futurebusiness practices.

\section{Theoretical Review}

\subsection{Framework of Risk Management System}

Risk Management Systemis a series of processes that are influenced by board of directors, management of the company, and other personnel. Risk Management is implemented within the scope of the overall strategy setting within the company. Those mentioned series of processes are designed to identify potential events that can have a negative impact on the company. As well, Risk Management is aimed to manage the company's risks in order to guarantee the achievement of the organizational goals. The concept of Risk Management applied in this research is based on the framework introduced by ISO 31000 described by the following figure.

The Risk Management framework is divided into 2 kinds of processes, i.e. Strategic Process and Tactical Process. Strategic process consists of 4 components, i.e. Leadership \& Commitment, Integration \& Design, Implementation, and Evaluation \& Improvement. Whereas Tactical Process covers the processes of communication and consultation, recording and reporting, and monitoring and review. The proper conduct of strategic and tactical processes will make Risk Management application work well.

\subsection{Leadership \& Commitment}

Leadership and Commitment is a vital component of the Risk Management implementation process. This is the work of Top Management of the company. Hence, Top Management is to lead and drive all stakeholders of the company to be fully committed to implement Risk Management System at all levels of organizational units within the company. There is an obligation to invite full participation of all stakeholders in term of Risk Management process in accordance with their respective responsibilities and authorities. Management's commitment is manifested (mandated) in the form of building and implementing all components of the Risk Management framework, making Risk Management policies, allocating the necessary resources, as well as assigning tasks, authority and accountability in all organizational levels.

\subsection{Integration \& Design}

The implementation of Risk Management System should be integrated into the company's business process. It relates to the structural design of the company. Company's Risk is managed by each part of the organizational structure. Every member in an organization is responsible for managing risks faced his or her unit. Therefore, Risk Management 
becomes an inseparable part of the company's business process. In designing the Risk Management framework, the company needs to study and correctly understand the internal and external strategic factors of the company.

\subsection{Implementation}

In implementing Risk Management, each organizational unit refers to the following framework:

- Develop specific plans including time and resources;

- Determine where, when and how different types of decisions within the organization, and by whom;

- Modifying the decision-making process when needed;

- Ensuring organizational arrangements in risk management are understood clearly and practically.

In this context, it is prerequisite that stakeholders at all levels of the organization should fully understand the importance of Risk Management for the better performance of the company. As well, they must also be fully committed to their tasks due to Risk Management implementation. Otherwise, the company will gain no fruitful achievement so far.

\subsection{Evaluation and Improvement}

To measure the effectiveness of the Risk Management framework, the organization must periodically measure the performance of Risk Management implementation due to the objectives, implementation plan, indicators, and expected behavior and determine the suitability of the achievement with the objectives of the organization. Continual improvement must be carried out to ensure the suitability, adequacy and effectiveness of the Risk Management framework implementation. Hence, the organization must develop corrective action plans and design proper tasks to improve the company's performance.

\subsection{Risk Management Process}

Slightly different from the strategic process components, Risk Management Guidelines incorporate a risk management process into a tactical process, which consists of:

\subsubsection{Communicate and Consult}

Communication and consultation will help relevant stakeholders smoothen the process of understanding the risks and the process of designing strategies and policies to develop. Effective communication is essential to ensure that those responsible stakeholders for implementing risk management and understanding

the basis for decision-making process. In addition, effective communication will also make them easy to comprehend why certain actions are needed.

Risk perception may differ from one to another stakeholder due to differences in assumptions and concerns with respect to the risks. Then, stakeholders' perceptions and reasons for accepting certain risks are identified and documented. Finally, stakeholders 'motivation and commitment must be driven by the company's management to ensure that Risk Management implementation work well.

\subsubsection{Establish the Context}

Stakeholders must understand the risk context faced by the company. Hence, the risk context covers so many elements, such as: company' strategic external and internal environment, the company's objectives, the company's business model, as well as the policy and regulatory framework of the company. Determining the context is vital to define the basic parameters of risks and to provide meaningful technical guidance for decisions in a more detailed perspective. Then, the stakeholders should consider the following concepts.

- The external and internal contexts are the external and internal environment in which the organization exists to achieve its goals.

- The context of Risk Management is the context in which Risk Management principles are applied.

- Risk criteria are the criteria to analyze the risks due to probability to occur. The management should determine risk criteria as analytical instrument to identify the risks. 


\begin{tabular}{|clcc|}
\hline Level & \multicolumn{1}{c}{ Criteria } & Deskription & Probability \\
\hline E & Must be happen & There will definitely be a risk & $80 \%<\mathrm{x}<100 \%$ \\
\hline D & Might happen & Risk is most likely to occur & $60 \%<\mathrm{x}<80 \%$ \\
\hline C & Moderat & The probability of the risk occurring is average & $40 \%<\mathrm{x}<60 \%$ \\
\hline B & Rarely happening & The probability of occurring is smaller than average & $20 \%<\mathrm{x}<40 \%$ \\
\hline A & Very rarely & Very low risk of possibility & $0 \%<\mathrm{x}<20 \%$ \\
\hline
\end{tabular}

Table 1: Likelihood Criteria of PT XYZ

\subsubsection{Inherent Risks}

It is the risk of not taking into account the control activities to reduce the risk to an acceptable level. Residual risk is the risk condition that is estimated to still exist after control activities being executed. While inherent risk is a risk condition when risk assessment is carried out.

\subsubsection{Risk Tolerance \& Risk Appetite}

In general, PT XYZ's risk appetite is within the range from medium to low level of risk coverage in the risk map. Figure 2 below risk map of PT XYZ.

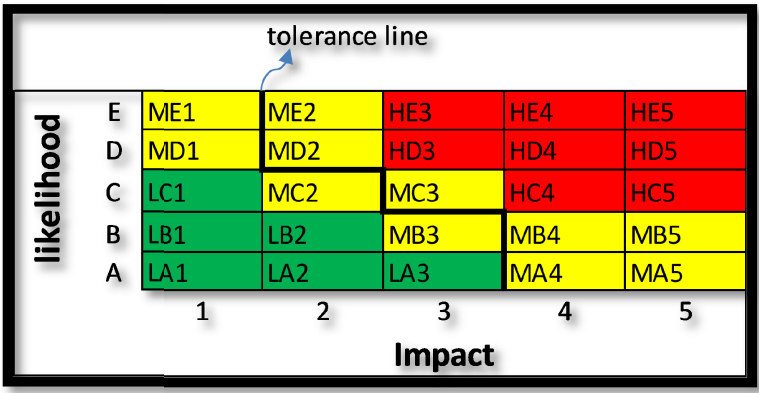

Figure 1:Risk Assessment Standard Matrix of PT XYZ

\subsubsection{Risk Map}

Risk map can also function as a dashboard for management that shows the position of risk, in inherent and residual conditions. By visually mapping Inherent Risk and Residual Risk, the management will be able to see the control scores created to manage risks to an acceptable level. The Risk Levels are categorized into three groups: High Risk, Medium Risk, and Low Risk.

\begin{tabular}{|c|c|c|}
\hline RISK & EXPLANATION & RISK NUM BER (RN) \\
\hline HIGH RISK & $\begin{array}{l}\text { "High Risk". It is necessary to control nisks to a chieve an } \\
\text { acceptable level of risk. Control can be done by } \\
\text { clarifying the re sponsibilites of each mana gement and } \\
\text { based on the Hierarchy of Risk Control besides the } \\
\text { involvement of Top Management is needed }\end{array}$ & $\begin{array}{l}\mathrm{D} 3 ; \mathrm{E3} ; \mathrm{C} 4 ; \mathrm{D} 4 ; \mathrm{E} 4 ; \\
\mathrm{C} 5 ; \mathrm{D} 5 ; \mathrm{E} 5\end{array}$ \\
\hline MEDIUM RISK & $\begin{array}{l}\text { "Moderate risk, need control". Control can be done by } \\
\text { clarifying the re sponsibilities of each management and } \\
\text { based on the Risk Control Hierarchy }\end{array}$ & $\begin{array}{l}\mathrm{D} 1 ; \mathrm{E} 1 ; \mathrm{C} 2 ; \mathrm{D} 2 ; \mathrm{E} 2 ; \\
\mathrm{C} 3 ; \mathrm{B} 4 ; \mathrm{B} 5\end{array}$ \\
\hline LOW RISK & $\begin{array}{l}\text { "Acceptable Risks". Control can be done through routine } \\
\text { procedures }\end{array}$ & $\begin{array}{l}\mathrm{A} 1 ; \mathrm{B} 1 ; \mathrm{C} 1 ; \mathrm{A} 2 ; \mathrm{B} 2 \\
\mathrm{~A} 3 ; \mathrm{B} 3 ; \mathrm{A} 4 ; \mathrm{A} 5\end{array}$ \\
\hline
\end{tabular}

Figure 2:Risk Level of PT XYZ

These are the authorities to be responsible to handle risks faced by the company:

- $\quad$ Risks that are above the risk tolerance line are under the full responsibility of the Board of Directors;

- The level of risk above the risk tolerance line is under the full responsibility of the Heads of Divisions;

- Risk below the full line of risk tolerance is under the responsibility of stakeholders at the operational level.

Context setting can refer to:

- Vision and mission of the company;

- RJP (Long Term Plan) of the company;

- RKAP (Corporate Work and Budget Plan);

- KDI (Kar Darfarmana Indientarr 
Establishing the context will smoothen the process of risk identification. The identification process should be carried out simultaneously with the process of Corporate Work and Budget Plan of the company. This is meant to prepare the implementation of Risk-Based Budgeting Plan methods in the future.

\subsection{Risks Identification}

Risk identification is the process of identifying risks, which includes identifying the causes of risks (risk causes), identifying the risk events, and identifying the impact of the risks (risk impacts) associated with the achievement of the goals set in the process of establishing the context.

\subsection{Risk Analysis}

Risk analysis is the process of analyzing the level of risk exposure by looking at the potential occurrence (likelihood / probability) and the level of impact. The common methods used in risk analysis are a Failure Mode Effect Analysis (FMEA), or Cause and Effect Analysis, or other relevant methods.

\subsection{Risk Evaluation}

Risk evaluation is a process to determine whether the identified risks are adequately monitored or need to be addressed. In addition, risk evaluation is to determine priority rankings. Risk is said to have an acceptable level whenever:

- The level of risk is low so there is no need for special handling;

- $\quad$ No risk treatment is available;

- Handling costs including insurance costs are higher than the benefits obtained if the risk is accepted;

- The opportunity for the risk is greater than the threat.

The evaluation step ensures that not all identified risks require further control plans. The results of the risk analysis will be submitted to the highest responsible risk manager in the work unit for validation.

\subsection{Risk Mitigation}

Risk mitigation is a process to filter identified risk in such a way in order to minimize the risk impact towards the company' business operations. Risk mitigation measures include identifying optional actions to handle risks, assessing these options, preparing and implementing a risk treatment plan. Risk mitigation can be divided into two types namely control and handling.

\subsubsection{Risk Control}

Risk Control is usually an effort that has been owned by the company and is routinely applied to anticipate the occurrence of risk. The tools of Risk Control can be in the form of Work Procedures, Work Instructions, and so on.

\subsubsection{Risk Handling}

Risk Handling is a newly made effort to treat risk in terms of eliminating or minimizing the identified risks because the existing efforts are inadequate.

\subsection{Risk Treatment}

Risk Treatment is an effort to treat the identified risks faced by the company. The followings are 4 kinds of Risk Treatments that are commonly applied by companies.

\subsubsection{Risk Avoidance}

Risk Avoidance is an alternative strategy to eliminate risk completely by not taking the business activities or projects that are estimated to have risks exceeding the organization's risk appetite. The best time to take a risk avoidance strategy is in the very early stages of a business activity. This strategy can also be taken when the activity or project has gone far enough, but there are changes in political or economic conditions that predictably may cause harm to the company.

The critical concern is the risk assessment process. This must be done perfectly. For example: the risk was previously assessed as acceptable. However, due to the lack of detailed initial assessment, the risk turns out to cause far greater impact than previously predicted. In this situation, the management of the company may change their mind for not continuing or delaying the activities. On the other hand, delaying or canceling these activities may also charge a high cost for the company. Therefore, the management should consider such situations in the process of making strategic decision.

\subsubsection{Risk Reduction)}

Risk Reduction is a risk treatment strategy to reduce the likelihood of the risk occurrence, or to reduce the impact exposure of the identified risk, or reduce both of them. The management has their own ways to determine which option is taken.

\subsubsection{Risk Transfer (Risk Sharing)}

Risk Transfer is an action to reduce the possibility of risk by fully or partially sharing or transferring the risk to other institutions. Transferring risk does not really mean reducing the severity of the risk, but only transferring to other parties at any cost. It must be realized that in the end the impact of the risk remains on the principal risk owner. This 
transfer of risk can pose a greater risk if the party receiving the transfer of risk is not aware of the risks they are facing and is actually unable to absorb the risk.

Modes to carry out this Risk Transfer include insurance, subcontracting, outsourcing, financial sharing agreements, and joint operations. Considering that Risk Sharing involves another party, it is necessary to consider what the other party's goals are, and the ability of both to carry out the work and absorb the risks that arise. Otherwise, this strategy will yield nothing but greater burden for both parties.

\subsubsection{Risk Acceptance}

Risk Acceptance is a strategy for not treating the identified risk. The consideration of taking this strategy may be because it is more economical to accept that risk compared to other risk treatment strategies. However, the management may take this type of strategy because the management concern that there are no other alternatives available to avoid the risk. Risk Acceptance is often also referred to as Risk Absorption, Risk Tolerance, or Risk Retention. Hence, the management should take into account these following considerations in order to take Risk Acceptance Strategy:

\subsubsection{Determination of Choice}

The management must be fully sure that all options of risk treatments have been carefully reviewed. Second, the management must be certain that there are no other choices suitable to treat the risk.

\subsubsection{Time and conditions}

When a choice of Risk Acceptance is taken, it should not be considered as a fait accompli situation (a state that cannot be refused). But conversely, the management should look into the possibilities to take any other strategies. Proactive monitoring and review are needed to see the direction of changes that occur. Good Risk Management will always ensure that there are no opportunities missed.

\subsubsection{Ability to Absorb Risk}

The choice to take Risk Acceptance strategy must be consciously made. The management should not rely on the principle that Risk Acceptance strategy is much more economical compared to other alternatives of risk treatment strategies. Hence, the management should consider the following questions before taking the Risk Acceptance strategy:

- What is the impact if the risk occurs?

- How likely is the impact of the risk?

- Is it true that the identified risk is only a single risk and not a risk that triggers other risks?

- If the risk will indeed lead to a series of other risks, is the impact only financial, or will it also have other impacts (for examples: the impact of reputation, the impact of stopping operations, the impact of work safety, and others)?

All processes in terms of Risk Management Application, such as risk identification, risk analysis, risk evaluation, and risk mitigation or risk treatment should be well documented in the form of a Risk Register.

\subsection{Monitoring \& Review}

The monitoring and review processes areactivities to ensure that the risk assessment and risk treatment have been carried out comprehensively, providing the necessary feedbacks and recommendations for performance improvement of the company. ISO 31000: 2018 states that monitoring and review must be planned as integrated parts in the risk management process. In addition, it is also necessary to explicitly determine responsible officers to conduct the monitoring and review processes.

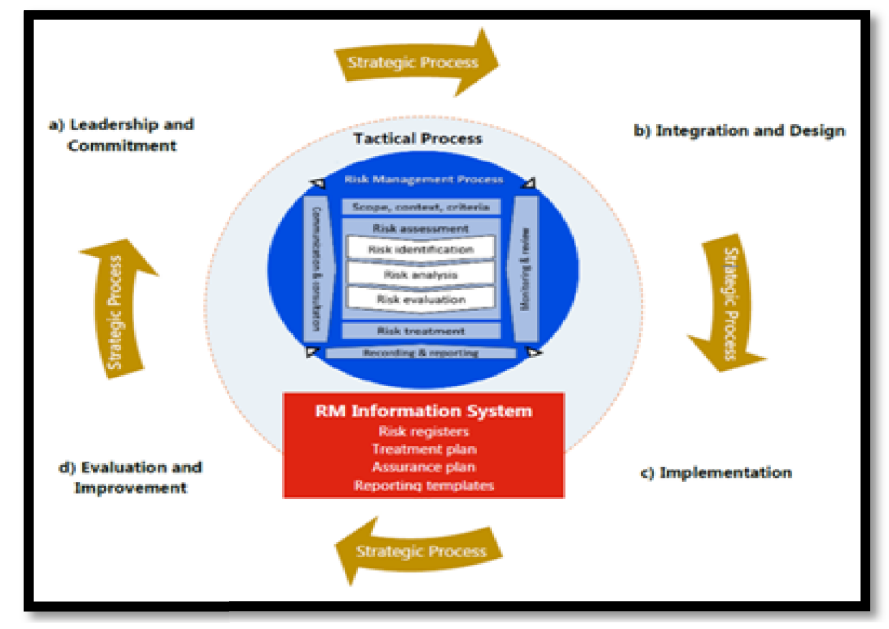

Figure 3: The Risk Management Framework Source : CRMS Indonesia - Survei Nasional Manajemen Risiko 2018 


\section{Research Methods}

\subsection{Research Design}

The research applies descriptive analysis methods, namely by exploring the empiric application of corporate Risk Management at PT XYZ in 2018. In this case, the researcher mainly applies 2 research methods, i.e. filed observation and depth interviews with research informants.

\subsection{Data Collection and Analysis}

The data used in this study are secondary data and primary data. Secondary data are data taken from secondary sources of data, such as: the company statistics, the company annual reports, literatures or references form academic journals. Primary data are data, which are collected from primary sources of data (research informants) by the researcher. The method used to collect the primary data is mainly depth interviews with the research informants, who are key persons within the company. The key informants of the research are those who empirically lead or dominantly participate on the process of risk management analysis in their own operational units. In case of unavailability of determined primary informant at any organizational unit, this research also provides secondary informant candidate to guarantee the completion of primary data collection. Hence, all research informants are completely interviewed. The data analysis used in this research is the descriptive qualitative analysis method. In doing so, the template or Risk Management Framework introduced by ISO 31000 is adopted.

\subsection{Interview Technique}

First of all, the researcher design points of interviews then set up interview guideline. This is meant to obtain information as comprehensive as needed from the determined research informants. In doing the interviews, the researcher also sets up interview technique to follow. Then, the research makes an appointment with the reserch informants to conduct the interviews. This is to prepare interview schedule with all research informants.

\subsection{Interview Guideline}

The Interview Guideline is set up to provide the researcher with the effective guidance in conducting the interviews with the research informants. The guideline covers questions to grab needed information from the research informants. The list of questions are as follows:

- What are the objectives to achieve?

- What Business Processes are carried out?

- $\quad$ Risk Identification Template:

- The name of the risk?

- Causes of the risk?

- Source of the risk?

- Impact of the risk?

- Risk Owner?

- Relevant department or unit?

- The measurement of Inherent Risk:

- Likelihood map?

- Impact map?

- Risk matrix of the measurement results?

- How to control risk over risks that have been identified:

- Risk management options?

- Work program?

- Run $100 \%$ ? or not run $100 \%$ ? Why?

- The measurement of Residual Risk:

- Likelihood map?

- Impact map?

- The risk matrix of the measurement results?

- How to handle Residual Risk:

- Risk treatment options?

- Risk mitigation?

- Cost?

- Implementation?

- What are the opportunities of identified risks?

- The Measurement of Risk after mitigation:

- Likelihood map?

- Impact map?

- The risk matrix of the measurement results?

Interview Technique InterviewTechnique contains points of guidances to conduct effective interview, such as: 
- Carry out an intimacy process for example by starting an interview with a light and interesting opening discussion.

- Doing probing to take advantage of digging up as much information as possible from the research informants. As well, exploring information as complete as possible in order to gain information relating to the objectives of the interview.

- $\quad$ Start from less sensitive questions to the most sensitive questions.

\subsection{Interview Schedule}

The interview schedule is made to provide the researcher with a remind system for the interview to be conducted. This contains, at least, name of informant, his or her position in the organization, date and time of interview, and place of interview.

\section{Results and Discussion}

The process of risk assessment is carried out starting from determining Department Risk, Division Risk up to Corporate Risk. This process is conducted by all company organizational units, starting from departmental to divisional level of work units within the company. Risk Owners are those who represent risk management in work units that are responsible for carrying out risk assessments, including: identification of risks, measurement of inherent risk, risk control, measurement of residual risk, handling of residual risk, and measurement of risk after mitigation.

Risk Appetite Dashboard is an instrument to tabulate the results of risk assessment processes done by Risk Owners within the company. Figure 4 below is the Risk Appetite Dashboard of PT XYZ as the result data analysis.

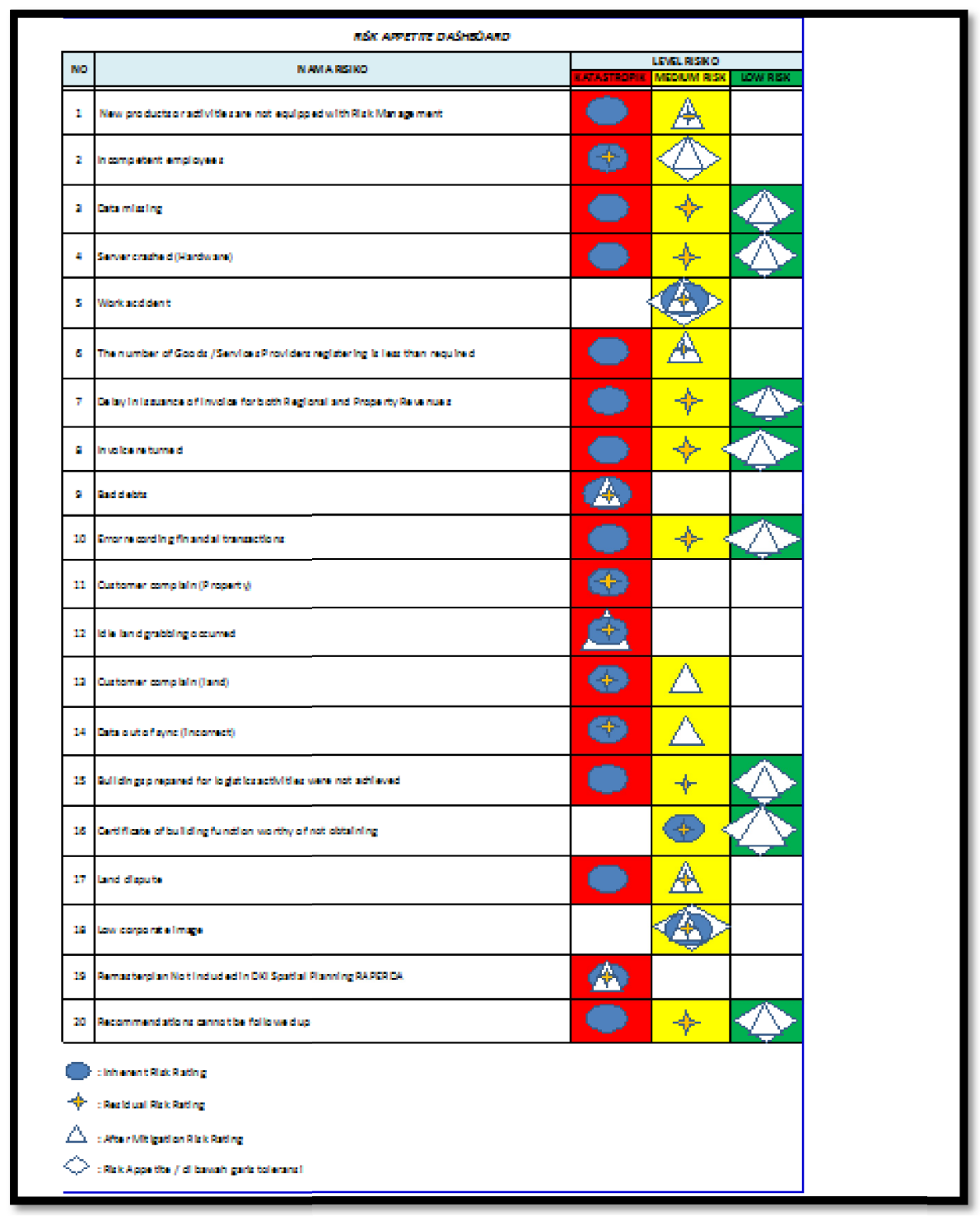

Figure 4: Risk Appetite Dashboard

Figure 4 above shows the identification the results of Risk Management process of PT XYZ done along the year of 2018, i.e. as follows: 


\subsection{NManageable Risks}

This research reveals that there are 9 manageable risks along the year of 2018. Manageable riks are risks that are successfully treated as the ham of the risk has decreased after taking action in the form of risk mitigation. This can be seen in the risk column with the diamond symbol.

\subsection{Unmanageable Risks}

There are 11 unmanageable risks identified in PT XYZ along the year of 2018. Unmanageable risks are risks that have not been successful treated (ineffective), because the catastrophic / emergency level of the risk after taking action in the form of risk mitigation cannot be reduced to below the tolerance line. This can be seen in the risk column with no diamond symbol.

\subsection{New Products or Activities Not Equipped with Risk Management Analysis}

The research uncovers new products or activities of the company without being equipped with Risk Managament Analysis. This happens because the process of Risk Management implementation is not integrated into the company business operations. This might also happen as there is no disclosure information related to these new products or activities. Therefore, the management should introduce mitigation actions to all Risk Owners within the company, such as:

- Dissemination of Risk Management Guidelines to all Divisions;

- Formulation of Risk-Based Corporate Work and Budget Planning (RKAP) starting from Budget Year of 2019;

- Formulation of SOP (Standard Operating Procedure) for Assessment and Risk Monitoring for Routine and NonRoutine activities;

- Periodic risk management awareness/campaign;

- Develop Investment Guidelines to regulate that new productor activities must be equipped with risk assessment analysis.

\subsection{Incompetence Employees}

This research finds the fact that there are still incompetence employees due to Risk Management application skill. This is because there is no comprehensive trainings in terms of Risk Management Analysis given to all Risk Owners within the company. Hence, the management should introduce mitigation actions, such as:

- Developing Training Need Analysis;

- Developing individual KPIs where risk analysis skill is included;

- Increase employee competency through training and education (Soft skills, Management Skills, and Leadership).

\subsection{Missing Data (Soft File)}

This research identifies that PT XYZ has ever undergone missing data caused by IT system problem. This may worsen the company business operations; therefore, some mitigation actions should be conducted, such as:

- Routine maintenance

- Governance of IT System space and equipment

- Installation of UPS \& ETS (2017)

- Backup data Server uses 100GB Google Drive

- Inspection of internet network installation

- Change servers periodically (every 3 years)

- Proposed building lightning rod test

- Relocation of server backups

\subsection{Server Has Damaged}

It is found that the server has ever damaged along theyear 2018. The main causes of this risk arethe condition of unstable electricity; the useful life of the server has been over; the spatial layout is incompatible with its function.

This risk may disrupt the data stored at the server, and other troubles in term of the Company's Data System operational activities. Accordingly, the management should conduct mitigation actions, such as:

- Change servers periodically (every 3 years)

- Routine care

- Governance of IT System space and equipment

- Purchase ETS (lightning resistant)

- Paid data backup (Cloud)

- Provide 2 units of Backupdata servers

\subsection{Work Accident}

Work accidents still exist along the year of 2018. The causes of work accidents are as follows:

- The lack of knowledge about Work Health and Safety (K3);

- Ignorance in the use of work tools to protect employees from work accidents

This risk has serious impact on the company, i.e. disrupt work activities; lawsuits; company reputation. Thus, the management should intriduce mitigation actions as follows:

- $\quad$ Propose K3 training programs as needed; 
- Provision of tools related to K3 for employees who carry out tasks (PPE);

- Application of the use of K3 tools for vendors and employees who carry out tasks within the PT XYZ environment;

- Application of SMK3 and ISO 45001: 2018 (Building systems and infrastructure).

\section{Conclusions and Recommendations}

\subsection{Conclusions} as follows:

Based on the data analysis using descriptive-qualitative methods, we can formulate main findings of this research

\subsection{The Risk Analysis Implementation}

This research reveals 133 risks spread over 26 Departmental levels of functional units within PT XYZ. This finding indicates that PT XYZ has already implemented risk analysis so far.

\subsection{Risk Level}

The identification of risk level within PT XYZ is as follows:

- High to Medium Risk level: 4 divisions

- High to Low Risk level: 4 divisions, and

- Low Risk level: 1 division.

This finding indicates that PT XYZ has also made Risk Level identification.

\subsection{Risk Management Analysis}

Based on the Risk Appetite Dashboard, it is identified that there are 9 manageable risks and 11 unmanageable risks. This shows the proof that PT XYZ, to what extent, has conducted Risk Management Analysis over the organizational units within the company.

\section{Recommendations}

Based on the results of the research, it is necessary to deliver recommendations covering Managerial Recommendations and Academic Recommendations.

\subsection{Managerial Recommendations}

- It is likely that the implementation of Risk Management Process in PT XYZ, which is Top-Down Process, still need full support from the Board of Directors of PT XYZ.

- In house training in terms of risk awareness building among stakeholders of PT XYZ need enhancement in the future. Consequently, the management should provide adequate budget to execute these mentioned training.

- Any department unit that have not yet completed the Risk Identification Process should be pushed to finalized this task. In this case, the management should know the real problem, and should overcome this problem immediately.

- Competencies in terms of environment analysis and risk prediction should be enhanced among the stakeholders within the company.

\subsection{Academic Recommendations}

Academic recommendations are very important for academicians to conduct future similar researches. This is aimed to provide the coming researches with information to improve the result of the next researches. The following points are addressed to the coming researchers to take into account.

- Quantitative methods to facilitate assessment and weighting in researches of Risk Management Practices;

- Conduct Case Studies in term of Risk Management Practices in other Industrial Estate Companies;

- Trying to conduct comparative case studies involving 2 industrial estate companies.

\section{References}

i. Agoes, Sukrisno. (2005). Peranan Internal Audit Department, Enterprise Risk Management, dan Good Corporate Governance Terhadap Pencegahan Fraud dan Implikasinya kepada Peningkatan Mutu Lulusan Perguruan Tinggi di Indonesia. Jakarta: Salemba Empat.

ii. Arrens, Alvin A., Elder, Randal J., \& Beasly, Mark S. (2010). Auditing and Assurance Services, An Integrated Approach. Thirteen Edition. New Jersey: Pearson Prentice Hall.

iii. BAPEPAM (2004). Keputusan Ketua Badan Pengawas Pasar Modal No. KEP- 29/PM/2004 (Peraturan No. IX.I.5) tentang Pembentukan dan Pedoman Pelaksanaan Kerja Komite Audit.

iv. BAPEPAM-LK (2006). Keputusan Ketuan Badan Pengawas Pasar Modal dan Lembaga Keuangan No. KEP134/BL/2006 (Peraturan No. X.K.6) tentang Kewajiban Penyampaian Laporan Tahunan Bagi Emiten atau Perusahaan Publik.

v. $\quad$------ (2008). Surat Edaran No. SE-02/BL/2008 tanggal 31 Januari 2008 tentang Pedoman Penyajian dan Pengungkapan Laporan Keuangan Emiten atau Perusahaan Publik Industri Pertambangan Minyak dan Gas Bumi. 
vi. - -------- (2008). Keputusan Ketua Badan Pengawas Pasar Modal dan Lembaga Keuangan No. KEP496/BL/2008 (Peraturan No. IX.I.7) tentang Pembentukan dan Pedoman Penyusnan Piagam Unit Audit Internal.

vii. Chambers, Andrew \& Rand Graham. (2010). The Operational Auditing Handbook: Auditing Business and IT Process. Second Edition. United Kingdom: John Willey \& Sons. Ltd.

viii. Daniri, Mas Achmad. (2005). Good Corporate Governance: Konsep dan Penerapannya Dalam Konteks Indonesia. Jakarta: PT. Ray Indonesia.

ix. Darmawati, Khomsiyah \& Rahayu. (2005). Hubungan Corporate Governance dan Kinerja Perusahaan. Jurnal Riset Akuntansi Indonesia, Volume 8 Nomor 1, 65-81. 1 Januari 2005

x. Djamaluddin Said, Megawati and Apollo,RiskAnalysis Of The Company Through Good Corporate As Intervening Business On Sustainable Company (Case Study on BEI Company Period 2011-2016)", International Journal Of Innovative Research \& Development India. Volume 7,issue 7, page 1-12, 2018

xi. Effendi, Muh. Arief. (2009). The Power of Good Corporate Governance: Teori dan Implementasi. Jakarta: Salemba Empat.

xii. Forum for Corporate Governance. (2011). What is Corporate Governance. 18 November 2011. http://www.fcgi.or.id/corporate-governance/about-good- corporate-governance.html

xiii. Global Corporate Governance Forum. (2003). Promoting Corporate Governance for Sustainable Development. 19 November 2011. Washington DC: The World Bank. http://www.ifc.org/ifcext/cgf.nsf/AttachmentsByTitle/ Forum_Review_2003/\$FILE/GCGF_Annual_Review.pdf

xiv. Gramling, Audrey A, \& Hermanson, D. R. (2006). What role is your internal audit function playing in corporate governance?. $\quad$ Internal Auditing, 21(6), $\quad 37-39 . \quad 18 \quad$ November 2011. http://search.proquest.com/docview/214393515? accountid=17242

xv. $\quad$-- (2006). Internal auditings role in ERM. The Internal Auditor, 63(2), 52-56,58. 9 Februari 2012. http://search.proquest.com/ docview/202751813?accountid=17242. Ikatan Akuntan Indonesia. (2011). Standar Profesional Akuntan Publik. Jakarta: IAI

xvi. Jensen, Michael C. \& Meckling, William H. (1976). Theory of the Firm: Managerial Behavior, Agency Costs and Ownership Structure. Journal of Financial Economics, October 1976, Vol. 3 No. 4.10 Oktober 2011. http://papers.ssrn.com/sol3/papers.cfm?abstract_id=94043.

xvii. Kementrian BUMN. www.bumn.go.id 